\title{
Torbergsens sykdom
}

\section{Femti år som lege har ikke stagget Torberg Torbergsens nysgjerrighet.}

- Ser du de bølgan der? Det liksom rippler nedover låret på ham.

Jeg stirrer fjetret på videoen av 17-åringen og de rullende bevegelsene som flytter seg rundt på kroppen hans.

Torberg Torbergsen er 75 år gammel, men ser atskillig yngre ut. Trolig er de hyppige skiturene med på å holde ham i form. Han kan spenne på seg skiene rett utenfor sykehusporten. Det er en av grunnene til at han er så glad i mørketiden. - Vinteren og mørketiden er det beste med Tromsø, hevder han.

- Han er ganske atletisk, ikke sant? Professoren peker på dataskjermen igjen. - Det er fordi musklene hans er i stadig ufrivillig aktivitet, han «trener» konstant.

- Hvordan fant du ut at det var noe spesielt med denne pasienten?

- Han var innlagt i nevrologisk avdeling på Ullevål sykehus da jeg hadde en utdanningsstilling der i 1973. Overlegene mine konkluderte raskt med at pasienten hadde Thomsens myotoni, og jeg fikk beskjed om å lage epikrise med den diagnosen.

Men Torbergsen var ikke fornøyd. Pasienten rakk så vidt å komme inn døren hjemme da assistentlegen ringte ham opp.

- Vi er nok ikke helt ferdige med deg likevel, sa jeg til ham.

Da Torbergsen undersøkte musklene til pasienten med elektromyografi, oppdaget han noe rart. - Jeg observerte ingen elektrisk aktivitet $\mathrm{i} \mathrm{EMG}-$ nålen når de rullende kontraksjonene passerte. Det ville man ha gjort dersom muskelcellekontraksjonen var utløst av spenningsfall over cellemembranen, som er den normale mekanismen for aktivisering av en muskel.

Torberg Torbergsen har etter hvert fått et stort nettverk av venner og kolleger både nasjonalt og internasjonalt. Én av dem er professor i nevrofysiologi Erik Stålberg, ved Uppsala universitet. - Erik trodde jeg fleipet da jeg ringte og sa jeg hadde en pasient med spontane muskelbevegelser uten påvisbar elektrisk aktivitet i muskelen. «Det er teoretisk umulig,» var svaret jeg fikk.

Torbergsen måtte ta med seg pasienten til Sverige og demonstrere funnene for de svenske nevrofysiologene før de trodde på assistentlegen. Året var 1974, og tilstanden fikk navnet Torbergsen's disease. I dag heter den rippling muscle disease.

- Nå kjenner vi den genetiske defekten, og årsaken til tilstanden som er en mutasjon i genet for et protein, caveolin-3, i muskelcellemembranen.

I ettertid har man funnet en familie på Gotland, og flere familier i Tyskland som har sykdommen. Det har også kommet noen spredte rapporter fra andre land. Men Torbergsens pasient og hans familie er den

\section{« umulig,» var svaret jeg fikk»}

første som noensinne er beskrevet. Han har fortsatt kontakt med pasienten som bortsett fra muskelrykningene lever godt med sin sykdom.

- Han kommer snart hit til kontroll. Vi skal se om en ultralydundersøkelse kan visualisere de rullende muskelkontraksjonene.

\section{Svart urin}

Vi har gått inn fra parkeringsplassen som ikke er stor nok til at det finnes ledige plasser etter kl 8 til tross for at Universitetssykehuset Nord-Norge ligger i åpent lende høyt og fritt over byen. Vi har krysset atriet med glasstak, og Torbergsen har beklaget at ikke bildene til Tromsøs mest kjente billedkunstner, Marit Boceli, henger her oppe i stedet for i kjelleretasjen. Veien til nevrofysiologisk avdeling er skiltet på norsk og på samisk. Nå løfter han et mintgrønt kaffekrus og unnskylder seg med at det er en gave fra den gangen han var avdelingsoverlege. «The boss» står det på koppen.

- Det hadde vært enda verre hvis jeg brukte den hjemme. Hva skulle kona si? humrer han.

Ute henger tåken tungt over fjelltoppene. En fiskebåt krysser fjorden. Torbergsen har ingen betenkeligheter med å bruke lørdagen på kontoret selv om han faktisk ble pensjonist i 2004.
- Kollegene har forsøkt å holde avskjedskaffe for meg mange ganger, sier han og ler igjen før han beklager at han ikke et mer fargerikt intervjuobjekt. - Jeg traff sønnen min tidligere i dag. Hva skal jeg si hvis journalisten spør om jeg har noen hobbier? spurte jeg ham. «Det er enkelt å svare på,» sa han. «Du har tre: arbeid, arbeid og arbeid.»

Torbergsen slår ut med hendene og innrømmer at det er noe sant i det. - Jeg gleder meg til å gå på jobb hver eneste dag. Det har jeg alltid gjort.

I flere år var han sjef for både nevrologisk og nevrofysiologisk avdeling.

- Trivdes du i lederrollen?

- Nei. Svaret kommer kontant. - Det ble for mye administrasjon.

Det er pasientkontakten og det kliniske arbeidet professoren setter pris på.

- Jeg er også glad for å kunne ha en klinisk innsikt i sykdommene til de pasientene jeg undersøker nevrofysiologisk. Det er fantastisk å ha muligheten til å se sykdomsbildet fra ulike synsvinkler.

Flere av pasientene har han fulgt over flere tiår.

- Jeg husker godt en pasient jeg møtte første gang i 1975. Dette er en kar som er glad i å gå på rypejakt. Men da rypa lettet, stivnet han i muskulaturen slik at han ikke klarte å skyte. Og da den rypeløse jegeren kom hjem, var urinen svart. Pigmentutskillelse $\mathrm{i}$ urinen ved anstrengelse kan forekomme ved metabolske muskelsykdommer. Men selv om en muskelbiopsi fra pasienten ble sendt til USA for undersøkelse ved avanserte laboratorier, kunne ikke mistanken om dette bekreftes. Til slutt ble pasienten utålmodig. «Nå har jeg gått her i 35 år,» sa han på en rutinekontroll. «Er det ikke snart på tide at jeg får vite hva som feiler meg?»

Like før dette hendte, var en ny mutasjon av et muskelprotein kalt fukudinrelatert protein blitt identifisert hos pasienter med liknende sykdomsbilder. Torbergsen sørget for at DNA fra pasienten ble analysert med tanke på dette. Da fikk han napp.

- Endelig kunne jeg fortelle pasienten at han hadde en genfeil som førte til at et protein i muskulaturen ikke oppfører seg helt normalt. 


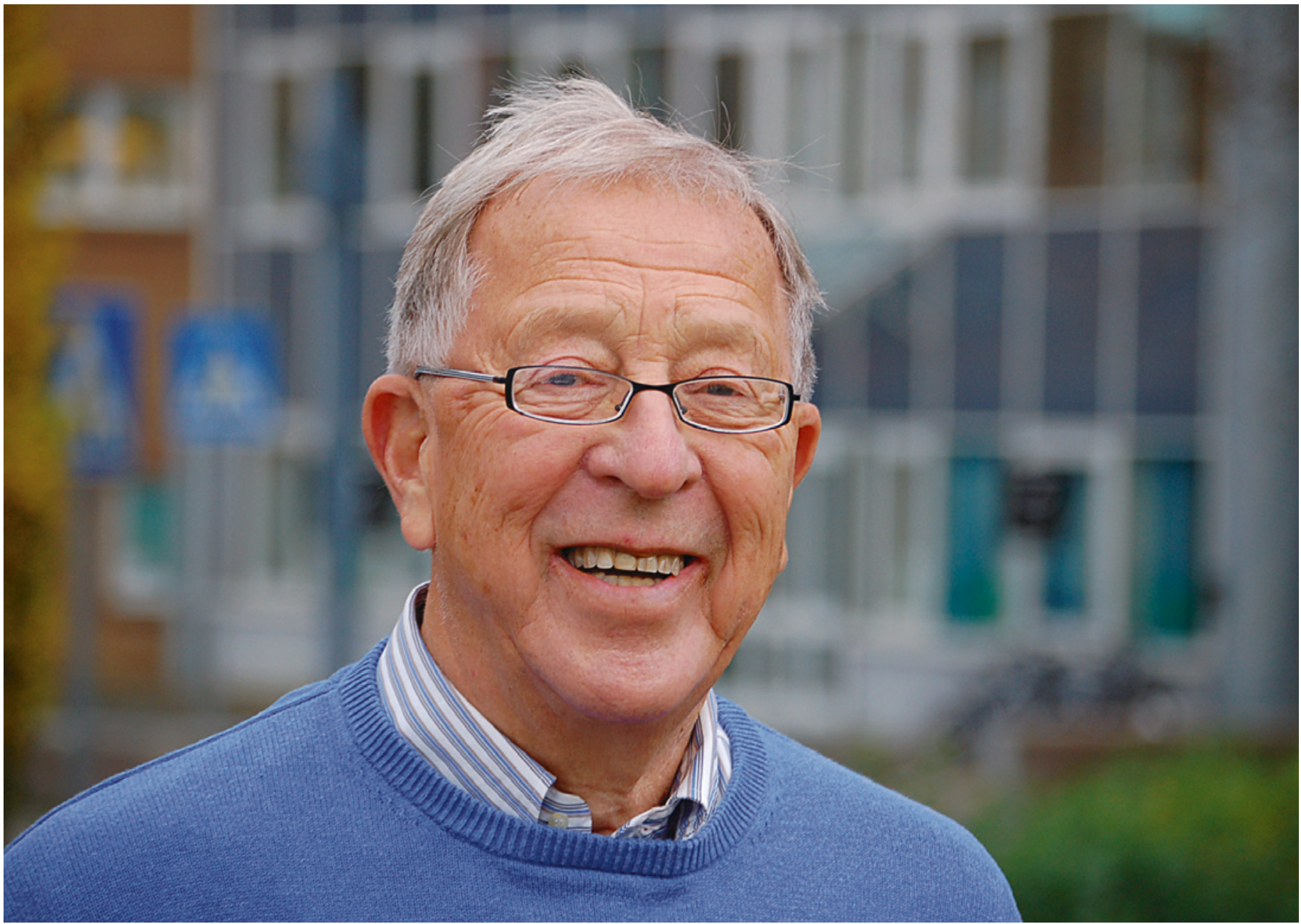

Foto Kari Tveito

\section{Torberg Torbergsen}

Født 31.3. 1937

- Cand.med. 1963

- Spesialist i nevrologi 1974

- Spesialist i klinisk nevrofysiologi 1989

- Professor emeritus i nevrologi og klinisk nevrofysiologi ved Universitet i Tromø

- Beskrevet muskelsykdommen «rippling muscle disease» (Torbergsens sykdom) i 1974
Pasienten ble så glad for svaret at han ga Torbergsen en kaktus som fikk navnet Fukutinia.

- Det var en veldig fin kaktus.

- Lever den ennå?

- Kaktusen er død. Men jeg har lagret bildet av den et sted.

\section{Skihopper med høydeskrekk}

Torberg Torbergsen ble født i Alta, men da Finnmark ble brent høsten 1944, ble familien evakuert til Vesterålen.

- En dag på slutten av krigen sto jeg utenfor hjemmet til besteforeldrene mine i Harstad. Plutselig kom over femti bombefly i lavt svev inn over byen.

Bombeflyene skulle senke ubåtene som lå i havnen utenfor kystbyen.

- Jeg husker at jeg så ansiktet på pilotene som føk over meg. I mange år tenkte jeg at det vel måtte være hukommelsen som spilte meg et puss, så nær bakken kunne de vel ikke ha fløyet. Men for noen år siden laget NRK en serie om krigen der de beskrev denne hendelsen. Flyene kom inn over
Harstad i en høyde på 30 meter over bakken for å unngå flyalarmen, ble det sagt. Så det var nok sant slik jeg husket det. Razziaer på søndagsmorgenen var også hverdagskost helt til far, som var motstandsmann, ble satt på Alstad og siden på Grini.

Men Torbergsen kan ikke huske at han syntes det var skummelt.

- Vi ble vant til det.

På Grini fikk Torbergsens far utdelt arbeidsklær av Einar Gerharden, som senere skulle bli landets statsminister.

- Far stemte alltid Arbeiderpartiet etter det.

På Sortland fikk sønnen en harmonisk barndom. Allerede da ble gleden ved ski og naturopplevelser vakt.

- Jeg var den eneste skihopperen med høydeskrekk.

Kona erobret han da hun var 16. I dag har de fire barn.

- Alle har navn som begynner på T faktisk. Tor, Trine, Tanja og Tina. Til den ene datteren vurderte vi navnet Tone. Det ville blitt Tone Torbergsdotter, samme navn som 
Harald Hardrådes kone. Men Tone ble i stedet Trine, en musikkterapeut som i flere år jobbet med musikkterapi i behandling av parkinsonpasienter, og også hadde eget sangkor for pasienter med denne sykdom. Selv om pasientene til vanlig hadde problemer med gange og tale, så sang de tekstene normalt og marsjerte uten problemer til musikk og kjente sanger.

Ingen av barna har gått i Torbergsens fotspor, de tre andre har satset på økonomi. Ikke er de så glad i mørketiden som ham heller. Alle sammen har flyttet sørover. Men selv føler Torbergsen seg så knyttet til landsdelen at han aldri har klart å reise fra Nord-Norge for annet enn kortere opphold i forbindelse med spesialistutdanningen og hyppige besøk på Rikshospitalets nevrofysiologiske laboratorium der han inntil for kort tid siden i perioder bidro i nevromuskulær diagnostikk. Men om sommeren reiser han til Bohuslän.

- Vi har hytte og seilbåt der nede.

Likevel er det den nordnorske naturen som står overlegens hjerte nærmest. Tiden som distrikslege i Kåfjord i Lyngen i unge år var fin og spesiell, og er kanskje den perioden han husker best fra sin lange karriere som lege.

- Kåfjord var en læstadiansk bygd hvor det var fint å være lege. Hvis noe gikk galt der, var det alltid Vårherres vilje og ikke doktorens feil! Men da Helsedirektoratet forespurte ham som eneste lege å dekke Skjervøy i tillegg til Nordreisa og Kåfjord som han allerede hadde ansvaret for, syntes han det ble for mye.

\section{Ydmyk nestor}

Torberg Torbergsen har hentet kaffe og kjeks. - Dessverre er ikke kantinen åpen på lørdager, sier han og bekymrer seg for om jeg er sulten. I to minutter sliter han med å få opp den gjenstridige kjekspakken.

- Som du ser er det ikke strengt nødvendig med tekniske evner for å bli nevrofysiolog, bemerker han tørt før vi setter tennene $\mathrm{i}$ hver vår kjeks.

- Hvorfor valgte du medisin i utgangspunktet?

- Det var på grunn av karakteran, kommer det spøkefullt. I ettertid angrer han seg. - Uff, det må du ikke sette på trykk, sier han beskjemmet på telefon fra Tromsø. - Karakterene var ikke så gode. For en flåsete kommentar!

Torbergsen er selvkritisk, en egenskap kollegene berømmer ham for: «Han er usedvanlig ydmyk til tross for et enormt kunnskapsnivå og sin lange erfaring.»

At det skulle bli nevrologi var også litt av en tilfeldighet.

- I 1967 kom en nederlandsk nevrolog til Tromsø. Før det fantes det ikke nevrolog i byen. Året etter begynte to assistentleger på det som skulle bli nevrologisk avdeling på sykehuset i Tromsø. Torberg Torbergsen var den ene.

- EEG måtte vi ta på Åsgård sykehus, for det hadde vi ikke utstyr til hos oss.

Etter hvert ble behovet for å kunne gjøre nevrofysiologiske undersøkelser større. I 1983 tok Torbergsen initiativ til å bygge opp en egen nevrofysiologisk seksjon i tilknytning til den nevrologiske avdelingen.

- Jeg påtok meg å lede den selv om jeg ikke var nevrofysiolog. Samtidig begynte jeg på spesialistutdanningen i klinisk nevrofysiologi og ble etter hvert spesialist i faget,

\section{«Flere av pasientene har han fulgt over flere tiår»}

forteller han. Frem til pensjonsalderen i 2004 har han ledet seksjonen.

- Klinisk nevrofysiologi i Norge er et lite fag, men det har blitt stadig viktigere. Faget har ekspandert, og repertoaret av nevrofysiologiske metoder har $ø$ kt betydelig fra den gang standard EEG-registreringer var stort sett enerådende innen faget. Man har utviklet avanserte elektromyografiske teknikker, og undersøkelser med fremkalt respons gir mulighet for å bestemme ledningshastigheter i sentrale nervebaner.

Nevrofysiologiske metoder blir også mer og mer benyttet i intensivavdelinger, både ved cerebrale symptomer og ved utredning av nevromuskulære symptomer som ved «critical illness» og Guillain-Barrés syndrom. Nevrofysiologisk metoder brukes i forbindelse med intraoperativ monitorering, ved ryggkirurgi og ved hjernekirurgi ved epilepsi. Utredning $\mathrm{i}$ forbindelse med søvnforstyrrelser er også blitt en viktig undersøkelse innen faget.

- Ethvert sykehus med nevrologisk avdeling bør også ha en spesialist i klinisk nevrofysiologi, mener professoren. - Alle testene vi gjør er basert på at vi undersøker organer med eksitabelt vev. Vi ser på elektriske potensialer som forandrer seg ved sykdom, det være seg i perifere nerver, muskulatur eller i hjernen. Dette er dynamiske undersøkelser som sier noe om funksjonen, og gir en annen forståelse av sykdomsprosesser enn for eksempel bildediagnostikk. EMG-undersøkelse av den elektriske aktiviteten i muskulatur og nevrografi - undersøkelse av ledningshastigheten i perifere nerver- er etter min mening uunnværlige metoder ved utredning av sykdommer i perifere nerver og muskulatur, understreker overlegen.

- I Tromsø undersøker vi rundt 1400 pasienter med EMG hvert år. I utgangs- punktet er det en litt ubehagelig undersøkelse, vi stikker jo nåler inn i musklene til pasienten.

Men Torbergsen klarer som regel å bygge opp tilliten hos pasientene slik at de villig lar han stikke dem.

- En gang undersøkte jeg en kvinne med myotoni i form av smertefulle kontraksjoner blant annet $i$ tungen. Om sommeren hadde hun med seg datteren til Tromsø på ferie, og da ville jeg gjerne gjøre EMG på datteren også. Men det hadde ikke jenta lyst til.

- Hva med litt feriepenger, spurte jeg. 100 kroner?

Fremdeles ville ikke jenta legge seg på benken.

- Jeg tror vi stoppet på 400 kroner. Da lot hun meg få stikke, og resultatet var ikke uten konsekvenser.

EMG har imidlertid fått konkurranse fra andre undersøkelser.

- Nevrologien og klinisk nevrofysiologi har forandret seg i stor grad i takt med inntoget av ulike bildeundersøkelser som CT og MR.

Han husker tilbake til tiden da de gjorde luftencefalografi, og da cerebral angiografi ble utført med arteriepunksjon på halsen.

- Den rivende utviklingen innen molekylær genetikk har også endret nevrologen og nevrofysiologens hverdag, ikke minst når det gjelder arvelige nevromuskulære sykdommer. Nå kan vi i større grad enn før påvise den molekylære defekten og få innsikt i patofysiologiske mekanismer bak pasientenes symptomer.

Genetisk, patologisk, nevrofysiologisk og nevrologisk avdeling ved universitetssykehuset i Tromsø har sammen bygd opp et nasjonalt senter for nevromuskulære sykdommer. Torbergsen har hatt en sentral rolle i prosessen.

- Man kan jo lure på hvor riktig det er at pasienter med alvorlige muskelsykdommer skal måtte reise helt til Tromsø for å bli utredet, påpeker han.

Beskjeden og ettertenksom er han visst alltid. Men resten av landets nevrofysiologer og nevrologer ser ikke ut til å være i tvil om hvor ekspertisen befinner seg.

- Om et par uker er det slutt, bedyrer han. Jeg skal bare følge opp noen pasienter $i$ et år til. Eller to.

\section{Kari Tveito}

kari.tveito@akersykehus.no

Oslo universitetssykehus 